\title{
PHYSIOLOGICAL AND SANITARY QUALITY OF DESICCATED AND STORED AZUKI BEAN SEEDS ${ }^{1}$
}

\author{
CÁSSIO JARDIM TAVARES ${ }^{2 *}$, PATRÍCIA CARDOSO FERREIRA ${ }^{2}$, ADRIANO JAKELAITIS ${ }^{2}$, JULIANA DE \\ FÁTIMA SALES ${ }^{2}$, OSVALDO RESENDE ${ }^{2}$
}

\begin{abstract}
The objective of this research was to evaluate the effects of using different herbicides as desiccants in pre-harvest and the effects of storage on the physiological and sanitary quality of azuki bean seeds (Vigna angularis Willd). The experiment was arranged in a randomized complete block design in a split plot scheme, with four replications. Four herbicides were tested: paraquat (400 g a.i. ha $\left.{ }^{-1}\right)$, glufosinate ammonium (400 g a.i. ha $\left.\mathrm{h}^{-1}\right)$, glyphosate $\left(720 \mathrm{~g}\right.$ a.i. ha $\left.{ }^{-1}\right)$, flumioxazin $\left(30 \mathrm{~g}\right.$ a.i. ha $\left.{ }^{-1}\right)$ and a control without herbicide application. In the subplots seed quality was tested in two evaluation periods: at harvest and six months after harvest. Desiccant was applied when the azuki beans were physiologically mature. We assessed the physiological and sanitary quality of the seeds using a vigour and seed health test. The use of glyphosate resulted in a higher incidence of abnormal seedlings and reduced size and weight of the seedlings. With paraquat and flumioxazin the physiological quality was maintained and there was reduced pathogen infestation in the seeds six months after harvest. Storage affected the physiological quality of the azuki bean seeds.
\end{abstract}

Keywords: Vigna angularis Willd. Vigor. Conservação de sementes. Tratamento de sementes.

\section{QUALIDADE FISIOLÓGICA E SANITÁRIA DE SEMENTES DE FEIJÃO-AZUKI DESSECADAS E ARMAZENADAS}

RESUMO - Objetivou-se nesta pesquisa avaliar o efeito de diferentes herbicidas aplicados como dessecantes em pré-colheita sobre a qualidade fisiológica e sanitária de sementes de feijão azuki (Vigna angularis Willd.) e armazenadas. Foi adotado o delineamento experimental em blocos casualizados, em esquema de parcelas subdivididas, com quatro repetições. Testaram-se nas parcelas cinco princípios ativos de herbicidas: paraquat (400 g i.a ha $\left.{ }^{-1}\right)$, glufosinato de amônio $\left(400 \mathrm{~g}\right.$ i.a ha $\left.{ }^{-1}\right)$, glyphosate $\left(720 \mathrm{~g}\right.$ e.a ha $\left.{ }^{-1}\right)$, flumioxazin $\left(30 \mathrm{~g} \mathrm{i}^{\mathrm{a}} \mathrm{ha}^{-1}\right) \mathrm{e}$ uma testemunha sem aplicação de herbicida; e nas subparcelas as duas épocas de armazenamento das sementes (colheita e 6 meses após a colheita). A aplicação dos dessecantes ocorreu na maturidade fisiológica do feijoeiro. Foi avaliado a qualidade fisiológica e sanitária das sementes através de teste de vigor e sanidade de sementes. O uso do herbicida glyphosate promoveu maior incidência de plântulas anormais e redução do tamanho e massa das plântulas. Os herbicidas paraquat e flumioxazin mantiveram a qualidade fisiológica das sementes e promoveram menor infestação de patógenos aos seis meses após a colheita. O armazenamento afetou a qualidade fisiológica de sementes de feijão azuki.

Palavras-chave: Vigna angularis Willd. Vigor. Conservação de sementes. Tratamento de sementes.

\footnotetext{
*Corresponding Author

${ }^{1}$ Received for publication in $02 / 11 / 2015$; accepted in $08 / 17 / 2015$.

Paper extracted from the master dissertation of the first author.

${ }^{2}$ Postgraduate Program in Agricultural Sciences, Instituto Federal Goiano, Rio Verde, GO, Brazil; cassio.tavares@ifgoiano.edu.br, patricia.cardoso2009@hotmail.com, ajakelaitis@yahoo.com.br, julianacefetrv@yahoo.com.br, osvresende@yahoo.com.br.
} 


\section{INTRODUCTION}

Azuki bean is mainly produced in Asia and consumed in China, Japan and Korea. In Brazil, there are no exact statistics on the number of producers, the size of the harvest or the area cultivated with azuki beans. They are consumed mainly in the Japanese colonies, especially in the form of sweets and in numerous oriental delicacies. They can be found in medium or large supermarkets, with a higher price than common beans (Phaseolus vulgaris L.) (ALMEIDA et al., 2013).

The harvest of the seeds of dry bean crop should ideally be performed immediately after physiological maturity, when the seeds have high vigour, a high germination rate and maximum dry matter accumulation (GUIMARÃES et al., 2012). However, at this stage the seed has a high water content as do the green leaves and branches that remain on the plant. This condition reduce the efficiency of mechanized harvesting and causes damage to seeds (COELHO et al., 2012).

Usually, after reaching physiological maturity the seeds remain in the field for some time and are exposed to changes in the environmental temperature and humidity, which can adversely affect the physiological quality. They are also subject to damage from insects and pathogens (DALTRO et al., 2010). The application of desiccant in pre-harvest is an alternative procedure that reduces the exposure of the physiologically mature seeds to unfavourable conditions in the field, because it allows early harvesting.

Adequately performed, the application of desiccant promotes uniformity of crop maturation, advances the harvesting time, does not cause losses in yield and can also generate seeds with high quality physical, physiological and sanitary characteristics, even when subjected to storage (LAMEGO et al., 2013).

However, depending on the type and mode of action of the product used for desiccation seed quality may be impaired, especially on storage, where deterioration can be either accelerated or delayed (LACERDA, 2005). However, storage is an important factor in the logistics of the production and marketing of agricultural products and has an important role in the preservation of the products after harvest (SMANIOTTO et al., 2014).

Seed quality is affected by the genotype, the edaphic and climatic conditions, and biotic factors, in addition to suboptimal temperature and humidity conditions during storage (ZUCHI et al., 2013), which cannot be avoided, but only minimised. The physiological quality of seeds is defined by their ability to perform their vital functions, characterised by longevity, viability and vigour (TOLEDO et al., 2009).

In this context, the aim of this study was to evaluate the effect of herbicides applied as desiccants in pre-harvest of azuki bean seeds and their effects on the physiological and sanitary quality of the stored seeds.

\section{MATERIAL AND METHODS}

The research was conducted at the Instituto Federal Goiano, Rio Verde, Goias, Brazil, situated at $17^{\circ} 48^{\prime} 67 " \mathrm{~S}$ and $50^{\circ} 54^{\prime} 18$ " $\mathrm{W}$ and an altitude of $754 \mathrm{~m}$. The experimental area has distrophic red oxisol which presented the following physicochemical characteristics determined in the depth 0-20 cm: pH $\left(\mathrm{CaCl}_{2}\right) \quad 5.2 ; 11 \mathrm{mg} \mathrm{dm}^{-3} \mathrm{P}$; $246 \mathrm{mg} \mathrm{dm}$ K; 5.77 cmolc $\mathrm{dm}^{-3} \mathrm{Ca}$; 1.63 cmolc dm ${ }^{-3} \mathrm{Mg} ; 0.03$ cmolc dm ${ }^{-3} \mathrm{Al} ; 64.6 \%$ base saturation; and a particle composition of $46 \%$ clay, $10 \%$ silt and $44 \%$ sand. The climate is Aw (Köppen) - tropical, with rainfall concentrated in the summer (October to April) and a well-defined dry season during the winter (May to September), with average annual rainfall ranging from 1200 to $1500 \mathrm{~mm}$. The rainfall $(\mathrm{mm})$, days with rain and average temperature $\left({ }^{\circ} \mathrm{C}\right)$ that occurred during the trial period are shown in Figure 1.

The experiment was arranged in a randomised complete block design in a split plot scheme with treatments replicated four times. In the plots four herbicides and a control without application were tested (Table 1); and in the subplots evaluation of the quality of harvested seeds at two timepoints was performed: at harvest with $12 \%$ seed moisture content and at six months after harvest. Each treatment plot was $4 \mathrm{~m} \times 5 \mathrm{~m}$, and useful area comprised four core lines, excluding the borders and $0.5 \mathrm{~m}$ at each end.

The soil was prepared by ploughing and disking twice. The sowing was semi-mechanised and was performed on November 28, 2013. The azuki bean was seeded in rows spaced $50 \mathrm{~cm}$ apart, at 18 seeds per metre, deposited at a depth of $4 \mathrm{~cm}$. Basic fertilisation was carried out in the planting furrow with $350 \mathrm{~kg} \mathrm{ha}{ }^{-1}$ of the formulation 02-20-18 $\left(\mathrm{N}, \mathrm{P}_{2} \mathrm{O}_{5}, \mathrm{~K}_{2} \mathrm{O}\right)$. After 25 days after sowing, topdressing was added with $60 \mathrm{~kg} \mathrm{ha}^{-1} \mathrm{~N}$ in the form of urea.

The experiment was maintained weed-free during the growing season by manual hoeing. As phytosanitary treatments the fungicide pyraclostrobin $\left(0.075 \mathrm{~kg}\right.$ a.i. $\left.\mathrm{ha}^{-1}\right)$ and the insecticide thiamethoxan $\left(0.060 \mathrm{~kg}\right.$ a.i. $\left.\mathrm{ha}^{-1}\right)$ were applied, at 28 and 42 days after sowing, respectively. 


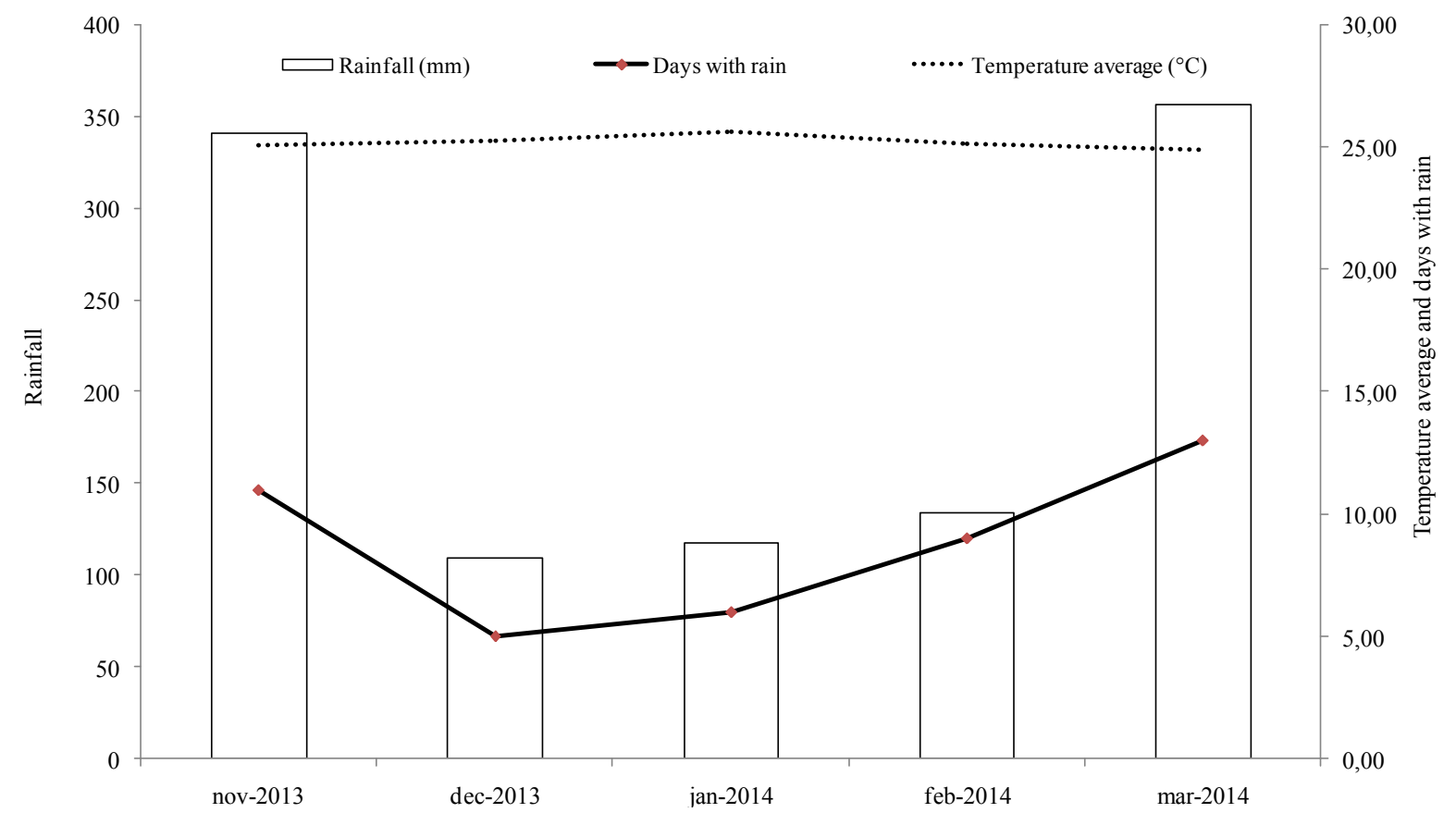

Figure 1. Rainfall, temperature average and number of days with rainfall between November 2013 and March 2014. Rio Verde, GO.

Table 1. Description of the treatments.

\begin{tabular}{cccc}
\hline & & \multicolumn{2}{c}{ Dosage } \\
\cline { 3 - 4 } Herbicide/control & Commercial product & $\begin{array}{c}\text { Active ingredient } \\
\left(\mathrm{g} \mathrm{a.i.} \mathrm{ha}^{-1}\right)\end{array}$ & $\begin{array}{c}\text { Commercial product } \\
\left(\mathrm{L} \mathrm{ha}^{-1}\right)\end{array}$ \\
\hline Paraquat & Gramoxone $^{(B)}$ & 400 & 2,0 \\
Glufosinate ammonium & Finale $^{(B)}$ & 400 & 2,0 \\
Glyphosate & Roundup $^{(B)}$ & $720^{*}$ & 1,0 \\
Flumioxazin & Flumyzin $^{(B)}$ & 30 & $60^{* *}$ \\
\hline Control & & - & \\
\hline
\end{tabular}

$*\left(\right.$ g a.e. $\left.\mathrm{ha}^{-1}\right) ; *\left(\mathrm{~g} \mathrm{ha}^{-1}\right)$.

The experiment was maintained weed-free during the growing season by manual hoeing. As phytosanitary treatments the fungicide pyraclostrobin $\left(0.075 \mathrm{~kg}\right.$ a.i. $\left.\mathrm{ha}^{-1}\right)$ and the insecticide thiamethoxan $\left(0.060 \mathrm{~kg}\right.$ a.i. $\left.\mathrm{ha}^{-1}\right)$ were applied, at 28 and 42 days after sowing, respectively.

The desiccant herbicide treatments were applied 68 days after sowing (DAS), when the plants were in the growth stage R7 - the time of physiological maturity, where at least one pod per plant had a typical mature coloration (yellow colour). The desiccant was sprayed using a $\mathrm{CO}_{2}$-pressurised sprayer that was calibrated to deliver $250 \mathrm{~L} \mathrm{ha}^{-1}$ of aqueous solution at 36.26 PSI using flat fan TT110-03 nozzles spaced $50 \mathrm{~cm}$ apart.

The azuki beans were harvested manually when the seeds presented $12 \%$ moisture content (wet basis) (Almeida et al., 2013). The seeds were placed in paper bags and stored at ambient conditions for a period of six months. The relative humidity $(\mathrm{RH})$ and temperature were recorded by a digital "data logger" (accuracy: $0.1{ }^{\circ} \mathrm{C}, 5.0 \% \mathrm{RH}$ ), obtaining average values over the experimental period for temperature of $25.4 \pm 3^{\circ} \mathrm{C}$ and $\mathrm{RH}$ of $67.3 \pm 3 \%$.
The physiological seed quality was evaluated by the following tests:

a) Water content - determined by the Rules for Seed Analysis (RAS), heating in an oven at $105 \pm$ $3{ }^{\circ} \mathrm{C}$ for 24 hours (BRASIL, 2009), with four replicates of 50 seeds. The result was expressed as the percentage of the wet weight lost during the heating.

b) Germination test - performed with four sub-samples of 50 seeds per treatment, packed in rolls of "germitest", moistened with distilled water in a volume equivalent to 2.5 times the mass of the dry substrate. The rolls were placed in a germination chamber, set at an alternating temperature of $30{ }^{\circ} \mathrm{C}$ for 12 hours with light and $20{ }^{\circ} \mathrm{C}$ for 12 hours without light. The counts were performed on the fourth and ninth days after the start of the test and the results were expressed as the percentage of seeds generating normal seedlings (BRASIL, 2009).

c) Emergence and emergence speed index conducted in a greenhouse, with four replications of 50 seeds sowed in sand at a depth of $3 \mathrm{~cm}$. The substrate was moistened to $70 \%$ of its field capacity at the time of sowing and afterwards irrigated by 
sprinkling three times a day. Daily counts were carried out until the tenth day after sowing, computing the seedling emergence over $1 \mathrm{~cm}$ in order to determine the seedling emergence speed index (ESI), according to Maguire (1962).

d) Length and seedling dry matter - using four replications of 20 normal seedlings from the emergence test ten days after sowing, hypocotyl and epicotyl length being measured using a ruler graduated in centimetres. To determine the dry mass, the seedlings were placed in paper bags and subjected to drying in an oven with forced air circulation at a temperature of $65{ }^{\circ} \mathrm{C}$ until constant mass. After drying, the mass of the samples was measured on an electronic balance accurate to $0.001 \mathrm{~g}$.

e) Electrical conductivity test - performed with four replications of 50 seeds for each treatment, which were previously weighed on an electronic balance (precision $0.01 \mathrm{~g}$ ). Seeds were placed in plastic cups containing $75 \mathrm{ml}$ of distilled deionised water and left soaking in a Biochemical Oxygen Demand (BOD) chamber at a constant temperature of $25{ }^{\circ} \mathrm{C}$. After 24 hours, the electrical conductivity of the solutions was measured using a digital conductivity meter (Tecnal 4MP Model). The results were expressed in $\mu \mathrm{S} . \mathrm{cm}^{-1} \cdot \mathrm{g}^{-1}$ seed (VIEIRA; RZYZANOWSKI, 1999).

f) Accelerated ageing — The test was conducted with four replicates of 50 seeds for each treatment in plastics boxes (gerbox) with an aluminium screen inside. $40 \mathrm{ml}$ of distilled water was added and 50 seeds were placed evenly on the screen. The boxes were capped and maintained in a germinating chamber regulated at a temperature of $41{ }^{\circ} \mathrm{C}$ for 24 hours. After ageing, the seeds were submitted to a germination test as described above and the results expressed as the percentage of seeds generating normal seedlings (MARCOS FILHO, 1994).

g) Sanitation test - the method used was a filter paper "blotter test", as described by Neergaard (1979). Three layers of previously dry sterilized filter paper were wetted with distilled water and autoclaved in $1 \%$ of sodium chloride, in plastic boxes (gerbox). Four replications of 100 seeds were placed on the filters using 25 seeds per box. Pathogen identification was carried out after seven days of incubation at $20 \pm 2{ }^{\circ} \mathrm{C}$ with a light regime of 12 hours light, 12 hours dark. At the end of this period the seeds were tested individually with the aid of a stereoscopic microscope with a magnification of up to $60 x$. Where necessary, preparations for microscopic identification of fungi were performed.

All of the data were submitted to analysis of variance using the $\mathrm{F}$ test. The treatment means were separated at the $5 \%$ level of significance by using the Tukey test.

\section{RESULTS AND DISCUSSION}

There were significant interactions between the effects of the desiccant herbicide and storage time for the following variables: percentage emergence, emergence speed index, hypocotyl length and total seedling length, hypocotyl dry mass and total seedling dry mass, and normal seedlings at the first count and normal seedlings after accelerated ageing. The desiccant herbicideswere a significant factor for electrical conductivity, abnormal seedlings and percentage of normal seedlings in the germination test and the time of evaluation was significant for electrical conductivity, length, root dry mass, abnormal seedlings and percentage of normal seedlings in the germination test (Tables 2 and 3 ).

Table 2. Summary of the analysis of variance of the variables analyzed azuki bean seeds (Vigna angularis Willd.) in function of the desiccant herbicide and the storage time.

\begin{tabular}{ccccccccc}
\hline \multirow{2}{*}{ Source of variation } & \multirow{2}{*}{$\mathrm{DF}$} & \multicolumn{9}{c}{ Mean squares } \\
\cline { 3 - 8 } & & $\mathrm{WC}^{\mathrm{l}}$ & $\mathrm{EC}$ & $\mathrm{E}$ & $\mathrm{ESI}$ & $\mathrm{HL}$ & $\mathrm{RL}$ & $\mathrm{TSL}$ \\
\hline Product (P) & 4 & $0,33^{\mathrm{ns}}$ & $438,08^{*}$ & $261,35^{* *}$ & $4,29^{*}$ & $1,70^{* *}$ & $2,18^{\text {ns }}$ & $6,71^{\mathrm{ns}}$ \\
Error-a & 12 & $0,42^{\mathrm{nnyyyyyy}}$ & 110,87 & 40,74 & 1,01 & 0,198 & 3,27 & 4,36 \\
Time (T) & 1 & $0,12^{\mathrm{ns}}$ & $6223,03^{* *}$ & $166,46^{\mathrm{ns}}$ & $19,61^{* *}$ & $78,37^{* *}$ & $94,58^{* *}$ & $345,39^{* *}$ \\
Interaction P x T & 4 & $0,25^{\mathrm{ns}}$ & $244,99^{\text {ns }}$ & $242,01^{*}$ & $6,77^{* *}$ & $3,45^{* *}$ & $4,30^{\text {ns }}$ & $11,31^{* *}$ \\
Error-b & 15 & 0,50 & 80,98 & 50,64 & 0,83 & 0,29 & 1,43 & 2,16 \\
\hline CV a (\%) & & 5,15 & 12,13 & 7,49 & 11,26 & 3,63 & 14,95 & 8,56 \\
CV b (\%) & & 5,66 & 10,37 & 8,45 & 10,21 & 4,40 & 9,89 & 6,03 \\
\hline
\end{tabular}

1/ WC - water content $(\% \mathrm{wb}), \mathrm{EC}$ - eletrical conductivity $\left(\mu \mathrm{S} . \mathrm{cm}^{-1} \cdot \mathrm{g}^{-1}\right), \mathrm{E}$ - percentage emergence $(\%)$, ESI - emergence speed index, HL - hypocotyl length $(\mathrm{cm}), \mathrm{RL}$ - primary root length $(\mathrm{cm}), \mathrm{TSL}-$ total seedling length $(\mathrm{cm}) . \mathrm{ns}, *^{*}, * *$ non significant, significant at 5 and $1 \%$, respectively by $\mathrm{F}$ test. 
Table 3. Summary of the analysis of variance of the variables analyzed azuki bean seeds (Vigna angularis Willd.) in function of the desiccant herbicide and the storage time.

\begin{tabular}{ccccccccc}
\hline \multirow{2}{*}{ Source of variation } & \multicolumn{7}{c}{ Mean squares } \\
\cline { 2 - 8 } & DF & HDM $^{1 /}$ & RDM & TDM & NS1 & AS & PN & NSAA \\
\hline Product (P) & 4 & $0,07^{*}$ & $0,02^{\text {ns }}$ & $0,14^{*}$ & $312,4^{*}$ & $355,25^{* *}$ & $292,35^{* *}$ & $347,85^{* *}$ \\
Error-a & 12 & 0,018 & 0,008 & 0,03 & 73,33 & 23,38 & 35,21 & 55,85 \\
Time (T) & 1 & $5,50^{* *}$ & $0,95^{* *}$ & $11,04^{* *}$ & $846,4^{* *}$ & $1464,1^{* *}$ & $1254,4^{* *}$ & $2220,1^{* *}$ \\
Interaction P x T & 4 & $0,07^{*}$ & $0,02^{\text {ns }}$ & $0,14^{*}$ & $257,9^{*}$ & $47,35^{\text {ns }}$ & $74,15^{\text {ns }}$ & $623,35^{* *}$ \\
Error-b & 15 & 0,02 & 0,01 & 0,04 & 68,40 & 40,30 & 63,53 & 27,76 \\
\hline CV a (\%) & & 26,20 & 34,51 & 24,45 & 12,96 & 30,70 & 7,30 & 12,68 \\
CV b (\%) & & 27,82 & 37,48 & 25,66 & 12,51 & 40,31 & 9,80 & 8,94 \\
\hline
\end{tabular}

1/ MSH - hypocotyl dry mass (g), RDM - root dry mass (g), TDM - total dry mass (g), NS1 - normal seedlings at the first count (\%), AS - abnormal seedlings in the germination (\%), PN - percentage of normal seedlings in the germination (\%), NSAA - normal seedlings after accelerated ageing (\%). ns, ${ }^{*}, * *-$ non significant, significant at 5 and $1 \%$, respectively by F test.

The water content of the seeds was not influenced by the product applied or by storage for six months (Tables 2 and 4), demonstrating that there were no major changes in the environmental conditions during storage. Water loss or gain during storage is associated with the permeability of the packaging and the conditions of the storage location, given that the packages may allow the exchange of water vapour with the atmosphere, and that the hygroscopicity of seeds is influenced by temperature and relative humidity (CARVALHO; NAKAGAWA, 2012).

Table 4. Water content (WC), eletrical conductivity (EC), abnormal seedlings in the germination (AS), percentage of normal seedlings in the germination (PN), root length (RL) e root dry mass (RDM) of the azuki bean (Vigna angularis Willd.) due to the application of different herbicidein pre-harvest and storage of the seeds for 6 months (6 MA).

\begin{tabular}{lcccccc}
\hline \multirow{2}{*}{ Treatments } & $\mathrm{WC}^{1 /}$ & $\mathrm{EC}$ & $\mathrm{AS}$ & $\mathrm{PN}$ & $\mathrm{RL}$ & $\mathrm{RDM}$ \\
\cline { 2 - 7 } & $\%$ b.u. & $\mu{\mathrm{S} . \mathrm{cm}^{-1} \cdot \mathrm{g}^{-1}}$ & $------\%------$ & \multicolumn{2}{c}{$\mathrm{cm}$} \\
\hline Control without herbicide & 12,83 & $82,10 \mathrm{ab}$ & $8,75 \mathrm{c}$ & $88 \mathrm{a}$ & 11,78 & 0,23 \\
Paraquat & 12,62 & $90,03 \mathrm{ab}$ & $10,5 \mathrm{c}$ & $85,5 \mathrm{a}$ & 11,40 & 0,33 \\
Glufosinate ammonium & 12,62 & $97,76 \mathrm{a}$ & $15,25 \mathrm{bc}$ & $80,25 \mathrm{ab}$ & 12,21 & 0,31 \\
Glyphosate & 12,49 & $78,82 \mathrm{~b}$ & $25,25 \mathrm{a}$ & $72,25 \mathrm{~b}$ & 12,75 & 0,22 \\
Flumioxazin & 12,28 & $85,18 \mathrm{ab}$ & $19 \mathrm{ab}$ & $80,5 \mathrm{ab}$ & 12,33 & 0,26 \\
\hline Harvest & 12,62 & $74,30 \mathrm{~b}$ & $9,7 \mathrm{~b}$ & $86,9 \mathrm{a}$ & $13,63 \mathrm{a}$ & $0,42 \mathrm{a}$ \\
6 MA & 12,51 & $99,25 \mathrm{a}$ & $21,8 \mathrm{a}$ & $75,7 \mathrm{~b}$ & $10,55 \mathrm{~b}$ & $0,12 \mathrm{~b}$ \\
\hline
\end{tabular}

$1 /$ Means followed by different letters in the column differ by Tukey test $(\mathrm{p}<0.05)$.

The electrical conductivity test is considered to be a biochemical test that reflects the state of integrity of the cell membrane system. The glyphosate used as desiccant showed better results for the maintenance of seed membrane system compared to glufosinate ammonium, which did not differ from the other treatments (Table 4). Paraquat applied as desiccant did not affect the integrity of the membranes and advanced the harvest time without harming the productivity or the quality of the bean seeds (COELHO et al., 2012).

Storage resulted in increased conductivity of the seeds (Table 4). These results were expected due to the gradual loss of integrity that the seed undergoes after the harvesting process until the death of the seed. This loss of integrity allows a greater release of electrolytes and consequently higher electrical conductivity.

Regarding the effect of the choice of desiccant on the germination test (Table 3 and 4), for the variables abnormal seedlings and percentage of normal seedlings the seeds treated with glyphosate and flumioxazin had higher numbers of abnormal seedlings compared to the herbicide paraquat and the control (no application). By contrast, in the control and in the treatments with paraquat higher percentage germination values were observed than for glyphosate herbicide, which did not differ from the other treatments. The use of glyphosate as a desiccant results in the development of seedlings with short roots, increases the number of abnormalities and also decreases the number of normal seedlings from soybean seeds, probably due to translocation of the product to the seed during desiccation (DALTRO et al., 2010).

After storage, an increase in the number of abnormal seedlings and a decrease in the percentage of normal seedlings were observed (Table 4). Padua and Vieira (2001) observed a reduction in seed viability and vigour during storage in seeds that were 
not desiccated in pre-harvest. Similarly, regardless of the type of packaging used, the germination of bean seeds (cv Perola) decreased when they were stored under non-laboratory environmental conditions (SILVA et al., 2010).

Studying the length and dry mass of seedlings or any part of them is an effective way to detect subtle differences in the vigour of the seeds (VANZOLINI et al., 2007). The use of glyphosate results in shorter hypocotyl length than flumioxazin (Table 5). Dry matter accumulation was also inferior in hypocotyls and whole seedlings, compared to the other pre-harvest treatments evaluated. (Table 6). After storage, there was a decrease in dry matter, however there were no differences between the treatments. Seedling length was also affected by storage. Thus, deterioration manifests itself during storage, causing negative effects on seed vigour (MARCANDALLI et al., 2011).

Assessing the whole length of bean seedlings Kappes et al. (2012) observed that there was no effect of age or paraquat application rates, however the application of paraquat at 30 days after flowering resulted in the greatest hypocotyl length. The use of glyphosate resulted in soybean seedlings with shorter length (DALTRO, 2010). Considering physiological seed quality, glufosinate ammonium is inappropriate for the desiccation of beans at pre-harvest (DOMINGOS et al., 1997).

Table 5. Hipocotyl lenght (HL) and total seedlings lenght (TSL) of the azuki bean (Vigna angularis Willd.) due to the application of different herbicide in pre-harvest and storage of the seeds for 6 months (6 MA).

\begin{tabular}{|c|c|c|c|c|}
\hline \multirow{2}{*}{ Treatments } & \multicolumn{2}{|c|}{$\mathrm{HL}^{1 /}(\mathrm{cm})$} & \multicolumn{2}{|c|}{ TSL (cm) } \\
\hline & Harvest & $6 \mathrm{MA}$ & Harvest & $6 \mathrm{MA}$ \\
\hline Control without herbicide & $14,31 \mathrm{aA}$ & $10,22 \mathrm{bB}$ & $27,50 \mathrm{aA}$ & $20,59 \mathrm{abB}$ \\
\hline Paraquat & $13,59 \mathrm{abA}$ & $9,79 \mathrm{bB}$ & $27,81 \mathrm{aA}$ & $18,36 \mathrm{bB}$ \\
\hline Glufosinate ammonium & $13,6 \mathrm{abA}$ & $10,58 \mathrm{bB}$ & $26,92 \mathrm{aA}$ & $21,69 \mathrm{abB}$ \\
\hline Glyphosate & $12,93 \mathrm{bA}$ & $10,09 \mathrm{bB}$ & $26,96 \mathrm{aA}$ & $19,57 \mathrm{bB}$ \\
\hline Flumioxazin & $14,05 \mathrm{aA}$ & $11,80 \mathrm{aB}$ & $27,47 \mathrm{aA}$ & $23,06 \mathrm{aB}$ \\
\hline $\mathrm{CV}$ a $(\%)$ & \multicolumn{2}{|c|}{3,63} & \multicolumn{2}{|c|}{8,56} \\
\hline $\mathrm{CV} b(\%)$ & \multicolumn{2}{|c|}{4,40} & \multicolumn{2}{|c|}{6,03} \\
\hline
\end{tabular}

1/ Means followed by different lowercase letters in the column and by uppercase letters in the row differby Tukey test $(\mathrm{p}<0.05)$.

Table 6. Hipocotyl dry mass (HDM) and total seedlings dry mass (TDM) of the azuki bean (Vigna angularis Willd.) due to the application of different herbicide in pre-harvest and storage of the seeds for 6 months (6 MA).

\begin{tabular}{lcccc}
\hline \multirow{2}{*}{ Treatments } & \multicolumn{2}{c}{$\mathrm{HDM}^{1 /}(\mathrm{g})$} & \multicolumn{2}{c}{ TDM $(\mathrm{g})$} \\
\cline { 2 - 5 } & Harvest & $6 \mathrm{MA}$ & Harvest & $6 \mathrm{MA}$ \\
\hline Control without herbicide & $0,85 \mathrm{aA}$ & $0,17 \mathrm{aB}$ & $1,30 \mathrm{aA}$ & $0,28 \mathrm{aB}$ \\
Paraquat & $0,91 \mathrm{aA}$ & $0,12 \mathrm{aB}$ & $1,46 \mathrm{aA}$ & $0,23 \mathrm{aB}$ \\
Glufosinate ammonium & $1,03 \mathrm{aA}$ & $0,12 \mathrm{aB}$ & $1,53 \mathrm{aA}$ & $0,25 \mathrm{aB}$ \\
Glyphosate & $0,58 \mathrm{bA}$ & $0,12 \mathrm{aB}$ & $0,89 \mathrm{bA}$ & $0,25 \mathrm{aB}$ \\
Flumioxazin & $1,04 \mathrm{aA}$ & $0,16 \mathrm{aB}$ & $1,45 \mathrm{aA}$ & $0,27 \mathrm{aB}$ \\
\hline \multicolumn{1}{c}{ CV a (\%) } & \multicolumn{3}{c}{24,45} \\
\multicolumn{1}{c}{ CV b (\%) } & 26,20 & \multicolumn{2}{c}{25,66} \\
\hline
\end{tabular}

1/ Means followed by different lowercase letters in the column and by uppercase letters in the row differby Tukey test $(\mathrm{p}<0.05)$

The effect of desiccation on seed quality was also evident after the accelerated aging test (Table 7) because there was a sharp decrease in the percentage of normal seedlings as a function of storage, except in the control where the observed values were statistically equal. There was no influence of the choice of desiccant at harvest, however, after storage, glufosinate ammonium and glyphosate showed inferior values of normal seedlings compared to the control, and were similar to the other treatments.

Artificial ageing is based on the fact that the deterioration rate of the seeds is increased on exposure to high levels of temperature and humidity, thus the largest effect is a decrease in the percentage of normal seedlings
(SANTOS et al., 2005). However, Kappes et al. (2012) observed that the germination percentage after artificial ageing of common bean seeds were not affected by the application of paraquat at $30,35,40$ and 45 days after flowering, at doses of $0,200,400$ and 600 g a.i. ha ${ }^{-1}$.

On the first germination count, the desiccants paraquat and glufosinate ammonium showed better results than the control, not statistically different from the others herbicides evaluated at pre-harvest (Table 7). After six months of storage, despite the loss in quality, seeds treated with the herbicide paraquat showed the best germination, superior to that observed for flumioxazin. The control, glufosinate ammonium and glyphosate treatments were statistically similar to each other. 
Table 7. Normal seedlings after accelerated ageing (NSAA) and normal seedlings at the first count (NS1) of the azuki bean (Vigna angularis Willd.) due to the application of different herbicide in pre-harvest and storage of the seeds for 6 months (6 MA).

\begin{tabular}{lcccc}
\hline \multirow{2}{*}{ Treatments } & \multicolumn{2}{c}{$\operatorname{NSAA}^{1 /}(\%)$} & \multicolumn{2}{c}{ NS1 (\%) } \\
\cline { 2 - 6 } & Harvest & $6 \mathrm{MA}$ & Harvest & $6 \mathrm{MA}$ \\
\hline Control without herbicide & $66,5 \mathrm{aA}$ & $64,0 \mathrm{aA}$ & $57,0 \mathrm{bA}$ & $66,5 \mathrm{abA}$ \\
Paraquat & $68,0 \mathrm{aA}$ & $56,0 \mathrm{abB}$ & $80,0 \mathrm{aA}$ & $69,5 \mathrm{aB}$ \\
Glufosinate ammonium & $65,0 \mathrm{aA}$ & $33,5 \mathrm{bB}$ & $76,5 \mathrm{abA}$ & $65,5 \mathrm{abA}$ \\
Glyphosate & $62,5 \mathrm{aA}$ & $35,0 \mathrm{bB}$ & $67,0 \mathrm{abA}$ & $55,0 \mathrm{abA}$ \\
Flumioxazin & $68,5 \mathrm{aA}$ & $54,5 \mathrm{abB}$ & $73,0 \mathrm{bA}$ & $51,5 \mathrm{bB}$ \\
\hline \multicolumn{2}{c}{ CV a (\%) } & \multicolumn{3}{c}{12,68} \\
\multicolumn{2}{c}{8,94} & \multicolumn{3}{c}{12,96} \\
\hline CV b (\%) & \multicolumn{3}{c}{12,51} \\
\hline
\end{tabular}

1/ Means followed by different lowercase letters in the column and by uppercase letters in the row differby Tukey test $(\mathrm{p}<0.05)$.

Generally the seeds had adequate emergence after harvest, with values above $90 \%$, except after application of glufosinate ammonium $(74.5 \%)$, and ESI values ranging from 9.5 to 11 . However, storage decreased the emergence of the seeds that were not desiccated, and reduced the ESI in all treatments (Table 8). Thus, the deterioration of the seed during storage is an inevitable and irreversible process (SILVA et al., 2014).

Paraquat and flumioxazin desiccants resulted in greater percentage emergence after storage compared with the control and glufosinate ammonium treatments. Seeds treated with flumioxazin showed higher ESI values than the other treatments that were all similar, at six months after the harvest. When applied early, at 30, 35 and 40 days after flowering at doses of 200 and $600 \mathrm{~g}$ a.i. $\mathrm{ha}^{-1}$, the paraquat herbicide favours the rapid emergence of bean seeds (KAPPES et al., 2012).

Table 8. Percentage emergence (E) e emergence speed index (ESI) of the azuki bean (Vigna angularis Willd.) due to the application of different herbicide in pre-harvest and storage of the seeds for 6 months (6 MA).

\begin{tabular}{lcccc}
\hline \multirow{2}{*}{ Treatments } & \multicolumn{2}{c}{$\mathrm{E}^{1 /}(\%)$} & \multicolumn{3}{c}{ ESI } \\
\cline { 2 - 6 } & Harvest & $6 \mathrm{MA}$ & Harvest & $6 \mathrm{MA}$ \\
\hline Control without herbicide & $94,5 \mathrm{aA}$ & $74,6 \mathrm{bB}$ & $9,5 \mathrm{aA}$ & $7,3 \mathrm{bB}$ \\
Paraquat & $91,0 \mathrm{aA}$ & $86,0 \mathrm{aA}$ & $9,6 \mathrm{aA}$ & $8,0 \mathrm{bB}$ \\
Glufosinate ammonium & $74,5 \mathrm{bA}$ & $77,5 \mathrm{bA}$ & $9,8 \mathrm{aA}$ & $6,9 \mathrm{bB}$ \\
Glyphosate & $90,0 \mathrm{aA}$ & $80,5 \mathrm{abA}$ & $10,0 \mathrm{aA}$ & $7,9 \mathrm{bB}$ \\
Flumioxazin & $95,5 \mathrm{aA}$ & $95,5 \mathrm{aA}$ & $11,0 \mathrm{aA}$ & $9,3 \mathrm{aB}$ \\
\hline \multicolumn{2}{c}{ CV a (\%) } & \multicolumn{3}{c}{7,49} \\
\hline \multicolumn{2}{c}{8,45} & \multicolumn{3}{c}{11,26} \\
\hline CV b (\%) & \multicolumn{3}{c}{10,21} \\
\hline
\end{tabular}

1/ Means followed by different lowercase letters in the column and by uppercase letters in the row differby Tukey test $(\mathrm{p}<0.05)$.

The percentage of seeds with associated fungi was less than $7 \%$ for all treatments, and the fungi were those commonly found in most crop species
(Table 9) limited to the genera Fusarium, Cladosporium, Alternaria, Aspergillus, Penicillium and Rizhopus. 
Table 9. Summary of the analysis of variance of the variables analyzed azuki bean seeds (Vigna angularis Willd.) in function of the desiccant herbicide and the storage time.

\begin{tabular}{cccccccc}
\hline \multirow{2}{*}{ Source of variation } & DF & \multicolumn{7}{c}{ Mean squares } \\
\cline { 3 - 8 } & & ALT $^{1 /}$ & ASP & CLA & FUS & PEN & RIZ \\
\hline Product (P) & 4 & $0,89^{* *}$ & $6,41^{* *}$ & $7,94^{* *}$ & $4,60^{* *}$ & $5,03^{* *}$ & $0,35^{*}$ \\
Error-a & 12 & 0,12 & 0,44 & 0,39 & 0,34 & 0,71 & 0,08 \\
Time (T) & 1 & $25,60^{* *}$ & 0,50 & $51,75^{* *}$ & $18,36^{* *}$ & $3,6^{*}$ & $3,96^{* *}$ \\
Interaction P x T & 4 & $0,32^{\text {ns }}$ & $2,84^{* *}$ & $7,38^{* *}$ & $5,03^{* *}$ & 1,93 & $0,52^{* *}$ \\
Error-b & 15 & 0,24 & 0,33 & 0,33 & 0,29 & 0,71 & 0,06 \\
\hline CV a (\%) & & 27,34 & 20,86 & 11,51 & 10,27 & 24,65 & 35,19 \\
CV b (\%) & & 38,57 & 18,12 & 10,65 & 9,55 & 24,65 & 30,99 \\
\hline
\end{tabular}

1/ ALT - Alternaria sp. (\%), ASP - Aspergillus sp. (\%), CLA - Cladosporium sp. (\%), FUS - Fusarium sp. (\%), PEN Penicillium sp. (\%), RIZ - Rizhopus sp. (\%). ns, *,**= non significant, significant at 5 and $1 \%$, respectively by $\mathrm{F}$ test.

The interactions between the variables (Tables 10 and 11) show that storage reduced the incidence of most pathogens in almost all treatments, with no differences depending on the desiccant used after six months. This is likely because the fungi do not develop well in conditions of low temperature and humidity (SANTOS et al., 2005). The exceptions were for Aspergillus and Penicillium pathogens that are adapted to these conditions.

Table 10. Occurrence of Aspergillus and Cladosporium of the azuki bean (Vigna angularis Willd.) due to the application of different herbicide in pre-harvest and storage of the seeds for 6 months (6 MA).

\begin{tabular}{|c|c|c|c|c|}
\hline \multirow{2}{*}{ Treatments } & \multicolumn{2}{|c|}{ Aspergillus $^{1 /}(\%)$} & \multicolumn{2}{|c|}{ Cladosporium (\%) } \\
\hline & Harvest & $6 \mathrm{MA}$ & Harvest & $6 \mathrm{MA}$ \\
\hline Control without herbicide & $2,85 \mathrm{bA}$ & $2,50 \mathrm{aA}$ & $5,15 \mathrm{cA}$ & $4,22 \mathrm{aB}$ \\
\hline Paraquat & $2,80 \mathrm{bA}$ & $3,30 \mathrm{aA}$ & $4,25 \mathrm{cA}$ & $4,15 \mathrm{aA}$ \\
\hline Glufosinate ammonium & $4,90 \mathrm{aA}$ & $3,70 \mathrm{aB}$ & $6,62 \mathrm{aA}$ & $4,27 \mathrm{aB}$ \\
\hline Glyphosate & $2,20 \mathrm{bA}$ & $2,80 \mathrm{aA}$ & $6,47 \mathrm{aA}$ & $4,32 \mathrm{aB}$ \\
\hline Flumioxazin & $1,82 \mathrm{bB}$ & 3,15 aA & $6,42 \mathrm{bA}$ & $4,47 \mathrm{aB}$ \\
\hline $\mathrm{CV}$ a $(\%)$ & \multicolumn{2}{|c|}{20,86} & \multicolumn{2}{|c|}{11,51} \\
\hline CV b (\%) & \multicolumn{2}{|c|}{18,12} & \multicolumn{2}{|c|}{10,65} \\
\hline
\end{tabular}

1/ Means followed by different lowercase letters in the column and by uppercase letters in the row differby Tukey test $(\mathrm{p}<0.05)$.

Table 11. Occurrence of Fusarium and Rizhopus of the azuki bean (Vigna angularis Willd.) due to the application of different herbicide in pre-harvest and storage of the seeds for 6 months (6 MA).

\begin{tabular}{|c|c|c|c|c|}
\hline \multirow{2}{*}{ Treatments } & \multicolumn{2}{|c|}{ Fusarium $^{1 /}(\%)$} & \multicolumn{2}{|c|}{ Rizhopus (\%) } \\
\hline & Harvest & $6 \mathrm{MA}$ & Harvest & $6 \mathrm{MA}$ \\
\hline Control without herbicide & $5,5 \mathrm{bcA}$ & $4,53 \mathrm{aB}$ & $0,98 \mathrm{bA}$ & $0,63 \mathrm{aA}$ \\
\hline Paraquat & $5,95 \mathrm{bA}$ & $4,85 \mathrm{aB}$ & $0,75 \mathrm{bA}$ & $0,40 \mathrm{aA}$ \\
\hline Glufosinate ammonium & $7,73 \mathrm{aA}$ & $5,15 \mathrm{aB}$ & $1,90 \mathrm{aA}$ & $0,38 \mathrm{aB}$ \\
\hline Glyphosate & $8,08 \mathrm{aA}$ & $5,03 \mathrm{aB}$ & $1,20 \mathrm{bA}$ & $0,63 \mathrm{aB}$ \\
\hline Flumioxazin & $4,48 \mathrm{cB}$ & $5,48 \mathrm{aA}$ & $0,90 \mathrm{bA}$ & $0,55 \mathrm{aA}$ \\
\hline $\mathrm{CV}$ a $(\%)$ & \multicolumn{2}{|c|}{10,27} & \multicolumn{2}{|c|}{35,19} \\
\hline $\mathrm{CV} b(\%)$ & \multicolumn{2}{|c|}{9,55} & \multicolumn{2}{|c|}{30,99} \\
\hline
\end{tabular}

1/ Means followed by different lowercase letters in the column and by uppercase letters in the row differby Tukey test $(\mathrm{p}<0.05)$. 
Overall, azuki bean seeds desiccated with the paraquat and flumioxazin herbicides had a lower incidence of fungi than those treated with other desiccants. Treatment with glufosinate ammonium and glyphosate resulted in the highest percentages of seeds infected with fungi in this evaluation. Chemical desiccation reduces the degree of infection of seeds by pathogens (INOUE et al., 2003). According to these authors, chemical desiccation changes the plant canopy by reducing the relative humidity, which probably contributes to a decreased level of infection of the pods and seeds. Nevertheless, rainfall after application can favour infection of the seeds by pathogens.

Despite the benefits of desiccant use in preharvest of crops and of storage there are discrepancies in the literature. These contrasting results may be due to the chemical properties of the desiccant, the dose, the species cultivated, the time of application, and the environmental conditions. In storage the temperature conditions, the water content and the relative humidity likely influence the performance of the products.

\section{CONCLUSIONS}

The use of glyphosate as a desiccant resulted in a higher incidence of abnormal seedlings and reduced the size and weight of the seedlings.

The use of paraquat and flumioxazin herbicides maintained the physiological seed quality, and resulted in a low level of pathogens in the stored seeds.

The herbicide paraquat therefore has the potential for use in the pre-harvest desiccation of azuki beans.

\section{ACKNOWLEDGEMENTS}

The authors thank the Instituto Federal Goiano, CAPES, FINEP (Public Call MCT / FINEP / CT-INFRA - PROINFRA - 02/2010) and EMBRAPA for the financial support and the facilities for carrying out the analyses.

\section{REFERENCES}

ALMEIDA, D. P. et al. Higroscopicidade das sementes de feijão adzuki. Científica, Jaboticabal, v. 41, n. 2, p. 130-137, 2013.

BRASIL. Ministério da Agricultura, Pecuária e Abastecimento. Regras para análise de sementes. Brasília, DF: MAPA/ACS, 2009. 395 p.

CARVAlHO, N. M.; NAKAGAWA, J. Sementes: ciência, tecnologia e produção. 5. ed. Jaboticabal, SP: FUNEP, 2012. 590 p.

COELHO, C. M. M. et al. Ação de dessecante na pré -colheita sobre a produtividade e a qualidade fisiológica de sementes crioulas de feijoeiro. Semina: Ciências Agrárias, Londrina, v. 33, n. 1, p. 2973-2980, 2012.

DALTRO, F. M. F. et al. Aplicação de dessecantes em pré-colheita: efeito na qualidade fisiológica de sementes de soja. Revista Brasileira de Sementes, Londrina, v. 32, n. 1, p. 111-122, 2010.

DOMINGOS, P.; SILVA, A. A.; SILVA, R. F. Qualidade da semente de feijão afetada por dessecantes, em quatro estádios de aplicação. Revista Brasileira de Sementes, Londrina, v. 19, $\mathrm{n}$. 2, p.275-282- 1997.

GUIMARÃES, V. F. et al. Produtividade e qualidade de sementes de soja em função de estádios de dessecação e herbicidas. Planta Daninha, Viçosa, v. 30, n. 3, p. 567-573, 2012.

INOUE, M. H. et al. Rendimento de grãos e qualidade de sementes de soja após a aplicação de herbicidas dessecantes. Ciência Rural, Santa Maria, v. 33, n. 4, p.769-770, 2003.

KAPPES, C. et al. Qualidade fisiológica de sementes e crescimento de plântulas de feijoeiro, em função de aplicações de paraquat em pré-colheita. Pesquisa Agropecuária Tropical, Goiânia, v. 42, n. 1, p. 9$18,2012$.

LACERDA, A. L. S. et al. Efeitos da dessecação de plantas de soja no potencial físiológico e sanitário das sementes. Bragantia, Campinas, v. 64, n. 3, p. 447-457, 2005.

LAMEGO, F. P. et al. Dessecação pré-colheita e efeitos sobre a produtividade e qualidade fisiológica de sementes de soja. Planta Daninha, Viçosa, v. 31, n. 4, p. 929-938, 2013.

MAGUIRE, J. D. Speed of germination: aid in selection and evaluation for seedling emergence and vigor. Crop Science, Madison, v. 2, n. 2, p. 176-177, 1962.

MARCANDALLI, L. H.; LAZARINI, E.; MALASPINA, I. C. Épocas de aplicação de dessecantes na cultura da soja: qualidade fisiológica de sementes. Revista Brasileira de Sementes, Londrina, v. 33, n. 2, p. 241-250, 2011.

MARCOS FILHO, J. Teste de envelhecimento acelerado. In: VIEIRA, R. D.; CARVALHO, N. M. (Ed.). Testes de vigor em sementes. Jaboticabal, 
SP: FUNEP, 1994. p. 133-149.

NEERGAARD, P. Seed Pathology. 2. ed. London: MACMILLAN PRESS, 1979. 839 p.

PÁDUA, G. P.; VIEIRA, R. D. Deterioração de sementes de algodão durante o armazenamento. Revista Brasileira de Sementes, Londrina, v. 23, n. 2, p. 255-262, 2001.

SANTOS, J. B. et al. Efeitos da dessecação de plantas de feijão sobre a qualidade de sementes armazenadas. Planta Daninha, Viçosa, v. 23, n. 4, p. 645-651, 2005.

SILVA, F. S. et al. Viabilidade do armazenamento de sementes em diferentes embalagens para pequenas propriedades rurais. Revista de Ciências Agro-Ambientais, Cáceres, v. 8, n. 1, p. 45-56, 2010 .

SILVA, M. M. et al. Qualidade fisiológica e armazenamento de sementes de feijão-comum produzidas no norte de Minas Gerais. Revista Agro@mbiente, Boa Vista, v. 8, n. 1, p. 97-103, 2014.

SMANIOTTO, T. A. S. et al. Qualidade fisiológica das sementes de soja armazenadas em diferentes condições. Revista Brasileira de Engenharia Agrícola e Ambiental, Campina Grande, v. 18, n. 4, p. 446-453, 2014.

TOLEDO, M. Z. et al. Qualidade fisiológica e armazenamento de sementes de feijão em função da aplicação tardia de nitrogênio em cobertura. Pesquisa Agropecuária Tropical, Goiânia, v. 39, n. 2, p. 124-133, 2009.

VANZOLINI, S. et al. Teste de comprimento de plântula na avaliação da qualidade fisiológica de sementes de soja. Revista Brasileira de Sementes, Londrina, v. 29, n. 2, p. 90-96, 2007.

VIEIRA, R. D; KRZYZANOWISKI, F. C. Teste de condutividade elétrica. In: KRZYZANOWISKI, F. C; VIEIRA, R. D; FRANÇA NETO, J. B. (Ed.). Vigor de sementes: conceitos e testes. Londrina: ABRATES, 1999, v. 1, cap. 4, p. 1-26.

ZUCHI, J. et al. Physiological quality of dynamically cooled and stored soybean seeds. Journal of Seed Science, Londrina, v. 35, n. 3, p. 353-360, 2013. 